\title{
Organodiphosphines in $\operatorname{PtP}_{2} \mathrm{X}_{2}(\mathrm{X}=\mathrm{As}, \mathrm{Ge}$ or Te$)$ derivatives - Structural aspects
}

https://doi.org/10.1515/mgmc-2020-0016

Received July 01, 2020; accepted July 16, 2020.

Abstract: Structural data of cis- $\mathrm{Pt}\left(\eta^{2}-\mathrm{P}_{2} \mathrm{~L}\right)(\mathrm{XL})_{2}(\mathrm{X}=\mathrm{Ge}$ or Te), cis-Pt $\left(\eta^{2}-P_{2} L\right)\left(\eta^{2}-X_{2} L\right)(X=A s, G e$ or Te) and trans$\mathrm{Pt}\left(\eta^{2}-\mathrm{P}, \mathrm{TeL}\right)_{2}$ were classified and analyzed. The chelating ligands create varieties of metallocyclic rings, which open in the sequence: $83.1^{\circ}(\mathrm{GeGeGe})<83.8^{\circ}\left(\mathrm{AsC}_{2} \mathrm{As}\right)<86.2^{\circ}$ $\left(\mathrm{PC}_{2} \mathrm{P}\right)<88.5^{\circ}\left(\mathrm{PC}_{2} \mathrm{Te}\right)<89.7^{\circ}\left(\mathrm{PC}_{3} \mathrm{P}\right) \sim 89.7^{\circ}\left(\mathrm{GeGe}_{2} \mathrm{Ge}\right)$. The structural data are compared and discussed with the complexes of an inner coordination spheres $\mathrm{Pt}\left(\eta^{2}-\mathrm{P}_{2} \mathrm{~L}\right)(\mathrm{XL})_{2}$ $\left(\mathrm{X}=\mathrm{O}, \mathrm{N}, \mathrm{CN}, \mathrm{B}, \mathrm{Cl}, \mathrm{S}, \mathrm{Se}, \mathrm{Si}, \mathrm{Br}\right.$ or I), Pt $\left(\eta^{2}-\mathrm{P}_{2} \mathrm{~L}\right)\left(\eta^{2}-\mathrm{X}_{2} \mathrm{~L}\right)$ $(\mathrm{X}=\mathrm{O}, \mathrm{N}, \mathrm{S}$, Se or $\mathrm{Si})$, and $\mathrm{Pt}\left(\eta^{2}-\mathrm{P}, \mathrm{SiL}\right)_{2}$.

Keywords: organodiphosphines; $\mathrm{PtP}_{2} \mathrm{X}_{2}(\mathrm{X}=\mathrm{As}, \mathrm{Ge}, \mathrm{Te}) ; \quad \mathrm{Te}(\mathrm{mes})_{3}$ structures; review; trans-influence

\section{Abbreviations:}

$\left(\mathrm{GePh}_{2}\right)_{3}$
$\mathrm{Ge}(\mathrm{H})\left(\mathrm{Bu}^{\mathrm{n}}\right)_{2}$
$\mathrm{Ge}(\mathrm{H})\left(\eta^{2}-\left(\mathrm{C}_{12} \mathrm{H}_{8}\right)\right.$
$\mathrm{Ge}(\mathrm{H})_{2}\left(\mathrm{C}_{12} \mathrm{H}_{17}\right)$
$\mathrm{Ge}(\mathrm{Me})(\mathrm{Ph})_{2}$
$\mathrm{Ge}(\mathrm{mes})_{3}$
$\mathrm{Ge}(\mathrm{Ph})_{2}$

1,1,2,2,3,3-hexaphenyltrigerman-1,3-diyl di-n-butylgermyl (biphenyl-2,2'-diyl) hydridogermyl 2,4,6-triethylphenyl)germyl methyl(diphenyl)germyl tri(mesityl)germyl di(phenyl)germyl

*Corresponding author: Milan Melník, Comenius University in Bratislava, Faculty of Pharmacy, Department of Pharmaceutical Analysis and Nuclear Pharmacy, Odbojárov 10, SK-832 32 Bratislava, Slovak Republic; Comenius University in Bratislava, Faculty of Pharmacy, Toxicological and Antidoping Center, Odbojárov 10, SK-832 32 Bratislava, Slovak Republic; e-mail: qmelnik@stuba.sk Peter Mikuš, Comenius University in Bratislava, Faculty of Pharmacy, Department of Pharmaceutical Analysis and Nuclear Pharmacy, Odbojárov 10, SK-832 32 Bratislava, Slovak Republic; Comenius University in Bratislava, Faculty of Pharmacy, Toxicological and Antidoping Center, Odbojárov 10, SK-832 32 Bratislava, Slovak Republic
$\mathrm{Me}_{2} \mathrm{P}\left(\mathrm{CH}_{2}\right)_{2} \mathrm{PMe}_{2}$

$(\mathrm{Ph})(\mathrm{Me}) \mathrm{As}\left(\mathrm{CH}_{2}\right)_{2} \mathrm{As}(\mathrm{Me})(\mathrm{Ph})$

$(\mathrm{Ph})(\mathrm{Me}) \mathrm{P}\left(\mathrm{C}_{6} \mathrm{H}_{4}\right) \mathrm{P}(\mathrm{M})(\mathrm{Ph})$

$\mathrm{Ph}_{2} \mathrm{P}\left(\mathrm{C}_{10} \mathrm{H}_{6}\right) \mathrm{PPh}_{2}$

$\mathrm{Ph}_{2} \mathrm{P}\left(\mathrm{CH}_{2}\right)_{2} \mathrm{PPh}_{2}$

$\mathrm{Te}\left(\mathrm{C}_{4} \mathrm{H}_{3} \mathrm{~S}\right)$

$\mathrm{Te}\left(\mathrm{C}_{5} \mathrm{H}_{8} \mathrm{O}\right) \mathrm{Te}$

$\mathrm{TePh}$ 1,2-bis(dimethylphos-

phino)ethane

bis(phosphylmethy-

larsene)ethane-1,2-diyl

bis(phenylmethylphos-

phino)phenylene-1,2-diyl

naphtalene-1,8-diyl bis(di-

phenylphosphine)

1,2-bis(diphenylphos-

phino)ethane

2-thienyltellurate

oxetane-3,3-diyldimethanetellurate

2,4,6-trimethylbenzenetellurate

phenyltellurate

\section{Introduction}

Comprehensive view on structural parameters of almost 2000 monomeric platinum complexes shows, that the square-planar Pt(II) complexes, by far prevail (Holloway and Melnik, 2002, 2003, 2004). One of such interest of a square-planar $\mathrm{Pt}(\mathrm{II})$ complexes is anti-tumor activity of $\mathrm{Pt}\left(\mathrm{NH}_{3}\right)_{2} \mathrm{Cl}$, known as "cisplatin" (Rosenberg et al., 1969). Over 200 platinum complexes exist in isomeric forms, which were classified and analyzed (Melník and Holloway, 2006), included are distortion (65\%), cis-trans (30\%), mixed (cis-trans + distortion) isomers, and ligand isomerization.

There are numerous published structural studies of organomonophosphines platinum complexes, which were classified and analyzed (Melník and Mikuš, 2015). There are also numerous structures of Pt(II) complexes with organomonophosphines (Holloway and Melnik, 2002, 2003, 2004; Melník and Mikuš 2019a, 2019b, 2020; Melník et al., 2019). The aim of this review is to classified and analyzed structural parameters of cis- $\mathrm{Pt}\left(\eta^{2}-\mathrm{P}_{2} \mathrm{~L}\right)(\mathrm{XL})_{2}$ $(X=G e, T e)$, cis-Pt $\left(\eta^{2}-P_{2} L\right)\left(\eta^{2}-X_{2} L\right)(X=A s, G e, T e)$ and trans-Pt $\left(\eta^{2}-P_{2} T e L\right)_{2}$. Their structural data are compared 
and discussed with $\mathrm{Pt}\left(\eta^{2}-\mathrm{P}_{2} \mathrm{~L}\right)(\mathrm{XL})_{2}(\mathrm{X}=\mathrm{O}, \mathrm{N}, \mathrm{CN}, \mathrm{B}, \mathrm{Cl}$, $\mathrm{S}, \mathrm{Br}, \mathrm{Se}, \mathrm{Si}, \mathrm{I}), \mathrm{Pt}\left(\eta^{2}-\mathrm{P}_{2} \mathrm{~L}\right)\left(\eta^{2}-\mathrm{X}_{2} \mathrm{~L}\right)(\mathrm{X}=\mathrm{O}, \mathrm{N}, \mathrm{S}, \mathrm{Se}, \mathrm{Si})$ and $\mathrm{Pt}\left(\eta^{2}-\mathrm{P}, \mathrm{SiL}\right)_{2}$ complexes.

\section{Cis- $P t\left(\eta^{2}-P_{2} L\right)\left(\eta^{2}-A s_{2} L\right)$ derivative}

Orthorhombic cis- $\left[\mathrm{Pt}\left\{\eta^{2}-(\mathrm{Ph})(\mathrm{Me}) \mathrm{P}\left(\mathrm{C}_{6} \mathrm{H}_{4}\right) \mathrm{P}(\mathrm{Me})(\mathrm{Ph})\right\}\left\{\eta^{2}-(\mathrm{Ph})\right.\right.$ (Me) $\left.\left.\mathrm{As}\left(\mathrm{CH}_{2}\right)_{2} \mathrm{As}(\mathrm{Me})(\mathrm{Ph})\right\}\right]$. $2 \mathrm{CF}_{3} \mathrm{SO}_{3}$ (at 200K) (Weir et al., 2009), is only example of such type (Figure 1). As can be seen both homobidentate ligands create five-membered metallocyclic rings with the values of L-Pt-L bite angles of $86.8(2)^{\circ}\left(\mathrm{PC}_{2} \mathrm{P}\right)$ and $83.8(2)^{\circ}\left(\mathrm{AsC}_{2} \mathrm{As}\right)$. The mean values of cis- and trans- P-Pt-As bond angles are $95.2( \pm 0.2)$ and $172.2( \pm 0.1)^{\circ}$, respectively. The mean values of Pt-L bond distances are $2.276( \pm 5)(\mathrm{L}=\mathrm{P})$ and $2.422( \pm 8) \AA(\mathrm{As})$, respectively.

\section{Cis-Pt( $\left.\eta^{2}-P_{2} L\right) G_{2}$ derivatives}

There are ten examples of the such inner coordination sphere about the Pt(II) atoms. These complexes from a coordination mode of the respective donor ligands can be divided into to the two sub-groups $\left.\mathrm{Pt}\left(\eta^{2}-\mathrm{P}_{2} \mathrm{~L}\right) \mathrm{GeL}\right)_{2}$ and $\operatorname{Pt}\left(\eta^{2}-P_{2} L\right)\left(\eta^{2}-G_{2} L\right)$.

\subsection{Cis-Pt $\left(\eta^{2}-P_{2} L\right)(G e L)_{2}$ derivatives}

There are seven complexes of this type of the inner coordination sphere about Pt(II) atom. In five complexes:

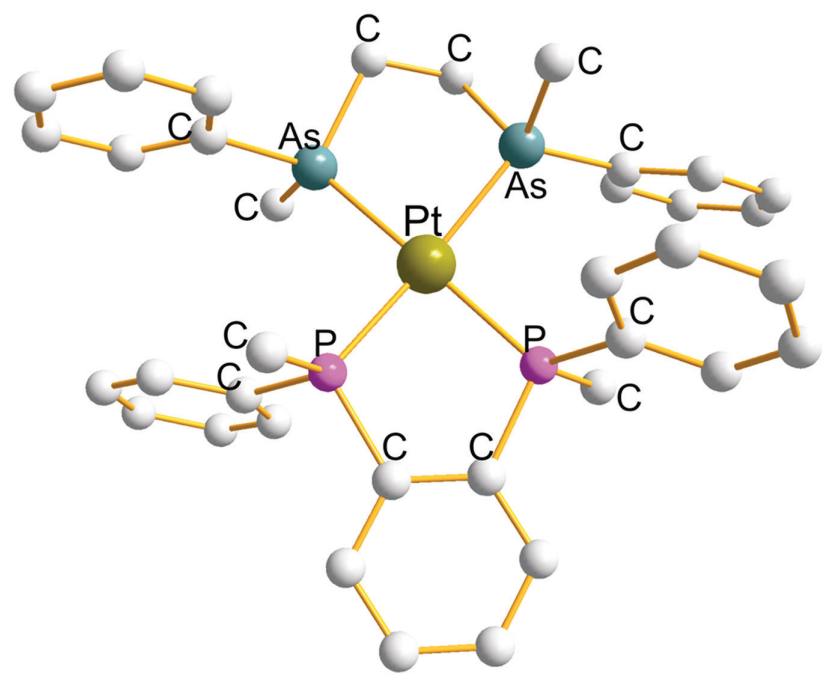

Figure 1: Structure of cis- $\left[\mathrm{Pt}\left\{\eta^{2}-(\mathrm{Ph})(\mathrm{Me}) \mathrm{P}\left(\mathrm{C}_{6} \mathrm{H}_{4}\right) \mathrm{P}(\mathrm{Me})(\mathrm{Ph})\right\}\left\{\eta^{2}-(\mathrm{Ph})\right.\right.$ $\left.\left.(\mathrm{Me}) \mathrm{As}\left(\mathrm{CH}_{2}\right)_{2} \mathrm{As}(\mathrm{Me})(\mathrm{Ph})\right\}\right]$ (Weir et al., 2009). monoclinic $\left[\mathrm{Pt}\left\{\eta^{2}-\mathrm{Me}_{2} \mathrm{P}\left(\mathrm{CH}_{2}\right)_{2} \mathrm{PMe}_{2}\right\}\left\{\mathrm{Ge}(\mathrm{Me})(\mathrm{Ph})_{2}\right\}_{2}\right]$ and monoclinic $\left.\quad\left[\mathrm{Pt}\left\{\eta^{2}-\mathrm{Ph}_{2} \mathrm{P}\left(\mathrm{CH}_{2}\right)_{2} \mathrm{PPh}_{2}\right\}\{\mathrm{Ge}(\mathrm{Me}) \mathrm{Ph})_{2}\right\}_{2}\right] \cdot \mathrm{C}_{6} \mathrm{H}_{6}$ (Mochidaetal., 2001), orthorhombic $\left[\mathrm{Pt}\left\{\eta^{2}-\mathrm{Ph}_{2} \mathrm{P}\left(\mathrm{CH}_{2}\right)_{2} \mathrm{PPh}_{2}\right\}\right.$ $\left.\{\mathrm{Ge}(\mathrm{mes})\}_{2}\right] \quad($ at $120 \mathrm{~K})$ and monoclinic $\left[\mathrm{Pt}\left\{\eta^{2-}\right.\right.$ $\left.\left.\mathrm{Ph}_{2} \mathrm{P}\left(\mathrm{CH}_{2}\right)_{2} \mathrm{PPh}_{2}\right\}\left\{\mathrm{Ge}(\mathrm{H})\left(\eta^{2}-\mathrm{C}_{12} \mathrm{H}_{8}\right)\right\}_{2}\right]$ (at $120 \mathrm{~K}$ ) (Arii et al., 2012), tetragonal $\left[\mathrm{Pt}\left\{\eta^{2}-\mathrm{Ph}_{2} \mathrm{P}\left(\mathrm{CH}_{2}\right)_{2} \mathrm{PPh}_{2}\right\}\left\{\mathrm{Ge}(\mathrm{H})\left(\eta^{2}-\mathrm{C}_{12} \mathrm{H}_{8}\right)\right\}_{2}\right]$ (at $100 \mathrm{~K}$ ) (Braddock-Wilking et al., 2009), and monoclinic $\left[\mathrm{Pt}\left\{\eta^{2}-\mathrm{Me}_{2} \mathrm{P}\left(\mathrm{CH}_{2}\right)_{2} \mathrm{PMe}_{2}\right\}\left\{\mathrm{Ge}(\mathrm{H})\left(\mathrm{Bu}^{\mathrm{n}}\right)_{2}\right\}_{2}\right]$ (at $113 \mathrm{~K}$ ) (Tanabe et al., 2011), each $\mathrm{R}_{2} \mathrm{P}\left(\mathrm{CH}_{2}\right)_{2} \mathrm{PR}_{2}$ ligand creates fivemembered metallocyclic ring $\left(\mathrm{PC}_{2} \mathrm{P}\right)$ with the mean value of P-Pt-P bite angles of $85.6( \pm 1.0)^{\circ}$. The mean value of $\mathrm{Ge}-\mathrm{Pt}-\mathrm{Ge}$ bond angles is $85.6( \pm 2.6)^{\circ}$ and the mean values of cis- and trans-P-Pt-Ge bond angles are $94.5( \pm 3.6)^{\circ}$ and $174.2( \pm 5.0)^{\circ}$, respectively. The mean values of Pt-P and Pt-Ge bond distance are 2.286 $( \pm 2)$ and 2.471 $( \pm 14) \AA$, respectively. In triclinic $\left[\mathrm{Pt}\left\{\mathrm{\eta}^{2}-\mathrm{Ph}_{2} \mathrm{P}\left(\mathrm{CH}_{2}\right)_{3} \mathrm{PPh}_{2}\right\}\{\mathrm{Ge}(\mathrm{mes})\}_{2}\right]$. 0.75hexane-1.58toluene (Arii et al., 2012) the chelating ligand creates six-membered metallocyclic rings $\left(\mathrm{PC}_{3} \mathrm{P}\right)$ with the value of $\mathrm{P}-\mathrm{Pt}-\mathrm{P}$ bite angle of $95.8^{\circ}$. The $\mathrm{Ge}-\mathrm{Pt}-\mathrm{Ge}$ bond angle is $81.4^{\circ}$. The mean $\mathrm{Pt}-\mathrm{L}$ bond distances are $2.282 \AA(\mathrm{L}=\mathrm{P})$ and $2.471 \AA$ ( $\mathrm{Ge}$ ) respectively.

\subsection{Cis-Pt $\left(\eta^{2}-P_{2} L\right)\left(\eta^{2}-G_{2} L\right)$ derivatives}

In monoclinic $\left[\mathrm{Pt}\left\{\eta^{2}-\mathrm{Me}_{2} \mathrm{P}\left(\mathrm{CH}_{2}\right)_{2} \mathrm{PMe}_{2}\right\}\left\{\eta^{2}-\left(\mathrm{GePh}_{2}\right)_{3}\right\}\right]$ (Figure 2) (Tanabe et al., 2009), two dissimilar chelating ligands build up a distorted square-planar environments

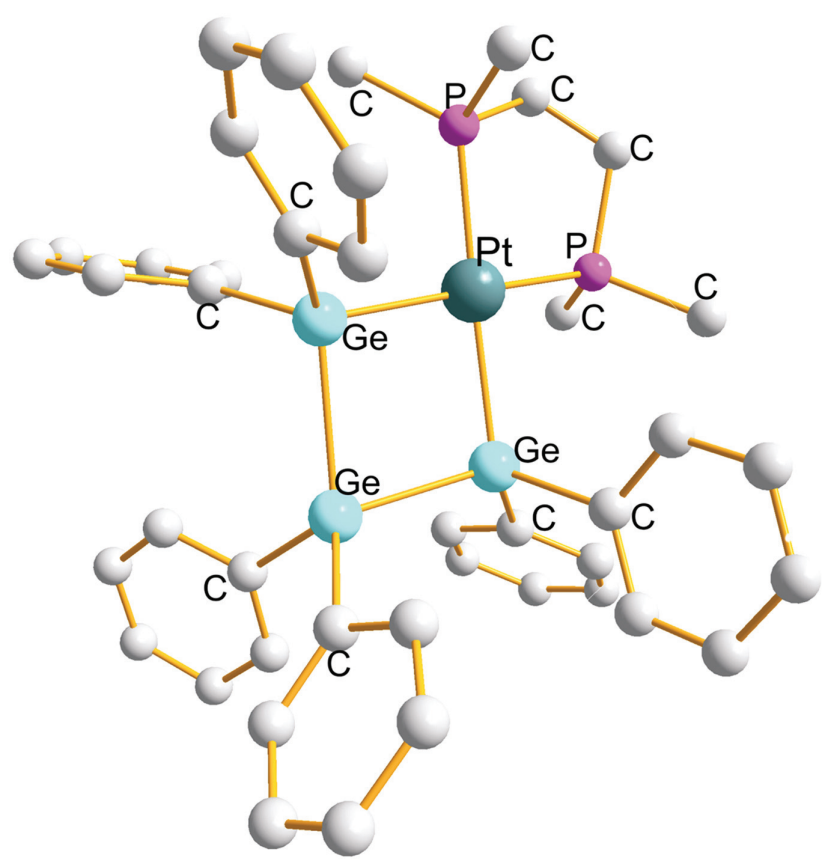

Figure 2: Structure of $\left[\mathrm{Pt}\left\{\mathrm{\eta}^{2}-\mathrm{Me}_{2} \mathrm{P}\left(\mathrm{CH}_{2}\right)_{2} \mathrm{PMe} \mathrm{e}_{2}\right\}\left\{\mathrm{\eta}^{2}-\left(\mathrm{GePh}_{2}\right)_{3}\right\}\right]$ (Tanabe et al., 2009). 
$\left(\mathrm{PtP}_{2} \mathrm{Ge}_{2}\right)$. The $\mathrm{P}, \mathrm{P}$-donor ligand creates five-membered metallocycle $\left(\mathrm{PC}_{2} \mathrm{P}\right)$ with the $\mathrm{P}-\mathrm{Pt}-\mathrm{P}$ angle of $85.9^{\circ}$, and $\left(\mathrm{GePh}_{2}\right)_{3}$ ligand form four-membered metallocycle (GeGeGe) with the value of $\mathrm{Ge}-\mathrm{Pt}-\mathrm{Ge}$ angle of $83.1^{\circ}$. The mean values of cis- and trans-P-Pt-Ge bond angles are $95.7( \pm 1.0)$ and $174.9( \pm 0.4)^{\circ}$, respectively. The mean values of Pt-P and Pt-Ge bond distances are $2.280( \pm 2)$ and 2.452 $( \pm 22) \AA$ A, respectively.

There are two complexes monoclinic $[\mathrm{Pt}$ $\left.\left\{\eta^{2}-\mathrm{Ph}_{2} \mathrm{P}\left(\mathrm{CH}_{2}\right)_{2} \mathrm{PPh}_{2}\right\}\left\{\eta^{2}-\left(\mathrm{Ge}\left(\eta^{2}-\mathrm{C}_{12} \mathrm{H}_{8}\right)\right)_{4}\right\}\right] . \mathrm{CH}_{2} \mathrm{Cl}_{2}$ (at $\left.100 \mathrm{~K}\right)$ (Braddock-Wilking et al., 2009) and orthorhombic $\left[\mathrm{Pt}\left\{\eta^{2}-\mathrm{Me}_{2} \mathrm{P}\left(\mathrm{CH}_{2}\right)_{2} \mathrm{PMe}_{2}\right\}\left\{\eta^{2}-\left(\mathrm{Ge}\left(\mathrm{Ph}_{2}\right)_{4}\right\}\right] \cdot\right.$ toluene (at $113 \mathrm{~K}$ ) (Tanabe et al., 2009) each $\mathrm{R}_{2} \mathrm{P}\left(\mathrm{CH}_{2}\right)_{2} \mathrm{PR}_{2}$ creates fivemembered metallocycles with the mean value of $\mathrm{P}-\mathrm{Pt}-\mathrm{P}$ bite angle of $85.7^{\circ}\left(\mathrm{PC}_{2} \mathrm{P}\right)$. Each bidentate Ge,Ge'-donor ligand forms five-membered metallocyclic ring with the mean $\mathrm{Ge}-\mathrm{Pt}-\mathrm{Ge}$ bite angle of $89.7^{\circ}\left(\mathrm{GeGe}_{2} \mathrm{Ge}\right)$. The mean values of cis- and trans-P-Pt-Ge bond angles are $92.4( \pm 1.4)$ and $175.1( \pm 1.1)^{\circ}$, respectively. The mean values of Pt-L bond distances are $2.285 \AA(\mathrm{L}=\mathrm{P})$ and $2.464 \AA$ (Ge), respectively.

\section{Cis-Pt $\left(\eta^{2}-P_{2} L\right) \mathrm{Te}_{2}$ derivatives}

There are seven examples of the such inner coordination sphere about the Pt(II) atom. These complexes from a coordination mode of the respective donor ligands can be divided into to the three sub-groups: $\mathrm{Pt}\left(\eta^{2}-\mathrm{P}_{2} \mathrm{~L}\right)(\mathrm{TeL})_{2}$, $\mathrm{Pt}\left(\eta^{2}-\mathrm{P}_{2} \mathrm{~L}\right)\left(\eta^{2}-\mathrm{Te}_{2} \mathrm{~L}\right)$, and $\mathrm{Pt}\left(\eta^{2}-\mathrm{P}, \mathrm{TeL}\right)_{2}$.

\subsection{Cis- $\mathrm{Pt}\left(\eta^{2}-\mathrm{P}_{2} \mathrm{~L}\right)(\mathrm{TeL})_{2}$ derivatives}

In five complexes a distorted square-planar geometry about the Pt(II) atom is build up by bidentate P,P'-donor ligand with pair of monodentate $\mathrm{Te}$ donor ligands. In two monoclinic $\left[\mathrm{Pt}\left\{\eta^{2}-\mathrm{Ph}_{2} \mathrm{P}\left(\mathrm{CH}_{2}\right)_{2} \mathrm{PPh}_{2}\right\}(\mathrm{TePh})_{2}\right]($ at $120 \mathrm{~K})$ and $\left[\mathrm{Pt}\left\{\eta^{2}-\mathrm{Ph}_{2} \mathrm{P}\left(\mathrm{CH}_{2}\right)_{2} \mathrm{PPh}_{2}\right\}\left\{\mathrm{Te}\left(\mathrm{C}_{4} \mathrm{H}_{3} \mathrm{~S}\right)\right\}_{2}\right]$ (at $120 \mathrm{~K}$ ) (Risto et al., 2007) each $\mathrm{Ph}_{2} \mathrm{P}\left(\mathrm{CH}_{2}\right)_{2} \mathrm{PPh}_{2}$ forms a five-membered metallocyclic ring with the mean value of $86.6^{\circ}$ $\left(\mathrm{PC}_{2} \mathrm{P}\right)$. In another three complexes: orthorhombic $[\mathrm{Pt}$ $\left.\left\{\eta^{2}-\mathrm{Ph}_{2} \mathrm{P}\left(\mathrm{CH}_{2}\right)_{3} \mathrm{PPh}_{2}\right\}\{\mathrm{Te}(\mathrm{mes})\}_{2}\right] \cdot 3 \mathrm{C}_{6} \mathrm{H}_{6}$ (at $100 \mathrm{~K}$ ) (Chauhan et al., 2013), monoclinic $\left[\mathrm{Pt}\left\{\eta^{2}-\mathrm{Ph}_{2} \mathrm{P}\left(\mathrm{C}_{10} \mathrm{H}_{6}\right) \mathrm{PPh}_{2}\right\}\{\mathrm{Te}(\mathrm{Ph})\}_{2}\right]$. 3toluene (at $133 \mathrm{~K}$ ), and triclinic $\left[\mathrm{Pt}\left\{\eta^{2}-\mathrm{Ph}_{2} \mathrm{P}\left(\mathrm{C}_{10} \mathrm{H}_{6}\right)\right.\right.$ $\left.\left.\mathrm{PPh}_{2}\right\}\left\{\mathrm{Te}\left(\mathrm{C}_{4} \mathrm{H}_{3} \mathrm{~S}\right)\right\}_{2}\right]$ (at $133 \mathrm{~K}$ ) (Karjalainen et al., 2017) each of the bidentate-P,P-donor ligand creates sixmembered metallocyclic ring with the mean value of P-Pt-P bite angle of $91.2^{\circ}\left(\mathrm{PC}_{3} \mathrm{P}\right)$. Structure of $[\mathrm{Pt}$ $\left.\left\{\eta^{2}-\mathrm{Ph}_{2} \mathrm{P}\left(\mathrm{C}_{10} \mathrm{H}_{6}\right) \mathrm{PPh}_{2}\right\}\left\{\mathrm{Te}\left(\mathrm{C}_{4} \mathrm{H}_{3} \mathrm{~S}\right)\right\}_{2}\right]$ (Karjalainen et al., 2017) is shown in Figure 3 as an example. The total mean values of Pt-L bond distances are $2.261 \AA(\mathrm{L}=\mathrm{P})$ and $2.585 \AA$ (Te).

\subsection{Cis- $\mathrm{Pt}\left(\eta^{2}-\mathrm{P}_{2} \mathrm{~L}\right)\left(\eta^{2}-\mathrm{Te}_{2} \mathrm{~L}\right)$ derivative}

In monoclnic cis- $\left[\mathrm{Pt}\left\{\eta^{2}-\mathrm{Ph}_{2} \mathrm{P}\left(\mathrm{C}_{10} \mathrm{H}_{6}\right) \mathrm{PPh}_{2}\right\}\left\{\eta^{2}-\mathrm{Te}\left(\mathrm{C}_{5} \mathrm{H}_{8} \mathrm{O}\right) \mathrm{Te}\right\}\right]$ (at $120 \mathrm{~K}$ ) (Figure 4) (Wagner et al., 2008) two chelating ligands, one with P,P-donor atoms and the other one with Te,Te-donor atom create a distorted square-planar

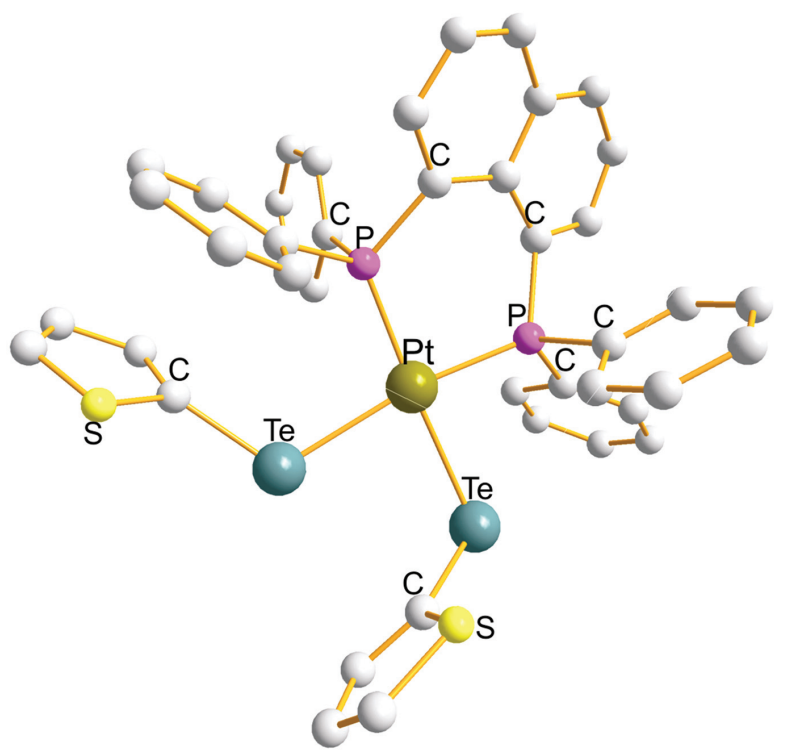

Figure 3: Structure of $\left[\mathrm{Pt}\left\{\eta^{2}-\mathrm{Ph}_{2} \mathrm{P}\left(\mathrm{C}_{10} \mathrm{H}_{6}\right) \mathrm{PPh}_{2}\right\}\left\{\mathrm{Te}\left(\mathrm{C}_{4} \mathrm{H}_{3} \mathrm{~S}\right)\right\}_{2}\right]$ (Karjalainen et al., 2017).

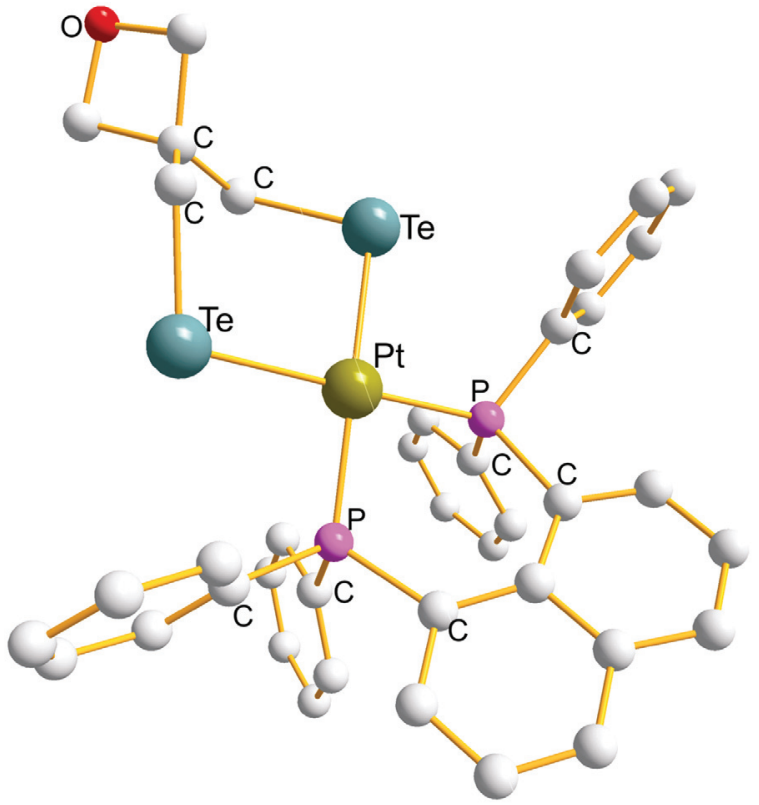

Figure 4: Structure of cis- $\left[\mathrm{Pt}\left\{\eta^{2}-\mathrm{Ph}_{2} \mathrm{P}\left(\mathrm{C}_{10} \mathrm{H}_{6}\right) \mathrm{PPh}\right\}\left\{\eta^{2}-\mathrm{Te}\left(\mathrm{C}_{5} \mathrm{H}_{8} \mathrm{O}\right) \mathrm{Te}\right\}\right]$ (Wagner et al., 2008). 
geometry about the $\mathrm{Pt}(\mathrm{II})$ atom $\left(\mathrm{PtP}_{2} \mathrm{Te}_{2}\right)$. Each chelating ligand forms six-membered metallocycles $\left(\mathrm{PC}_{3} \mathrm{P}\right)$ and $\left(\mathrm{TeC}_{3} \mathrm{Te}\right)$ with the values of $\mathrm{L}-\mathrm{Pt}-\mathrm{L}$ bite angles of $88.3^{\circ}$ and $90.8^{\circ}$, respectively. The mean values of cis- and trans-P$\mathrm{Pt}-\mathrm{Te}$ bond angles are $90.6^{\circ}$ and $175.0^{\circ}$, respectively. The mean values of Pt-L bond distances are $2.254 \AA$ (P) and $2.627 \AA$ (Te).

\section{Trans- $\mathrm{Pt}\left\{\eta^{2}-\mathrm{P}, \mathrm{TeL}\right)_{2}$ derivative}

Triclinic trans-[ $\left[\mathrm{Pt}\left\{\eta^{2}-\mathrm{Ph}_{2} \mathrm{P}\left(\mathrm{C}_{6} \mathrm{H}_{4}\right) \mathrm{TePh}\right\}_{2}\right]\left[\mathrm{Pt}(\mathrm{SCN})_{4}\right] \cdot 2 \mathrm{dmf}$ (Gysling and Luss, 1984) consists from well separated $\left[\mathrm{Pt}\left\{\eta^{2}-\mathrm{Ph}_{2} \mathrm{P}\left(\mathrm{C}_{6} \mathrm{H}_{4}\right) \mathrm{TePh}\right\}_{2}\right]^{2+}$ (Figure 5) and $\left[\mathrm{Pt}(\mathrm{SCN})_{4}\right]^{2}$. In the complex cation a distorted square-planar geometry about Pt(II) atom is build up by a pair of heterobidentate$\mathrm{P}$,Te donor ligands. Each heterochelating ligand creates five-membered metallocyclic ring with the mean $\mathrm{P}-\mathrm{Pt}-\mathrm{Te}$ bite angle of $88.5^{\circ}\left(\mathrm{PC}_{2} \mathrm{Te}\right)$. The values of trans-P-Pt-P and $\mathrm{Te}-\mathrm{Pt}-\mathrm{Te}$ bond angles is $178^{\circ}$. The mean values of Pt-L bond distances are 2.306(1) $\AA(\mathrm{L}=\mathrm{P})$ and 2.575(1) $\AA$ (Te), respectively.

\section{Conclusions}

This review covers structural parameters of monomeric platinum complexes with an inner coordination spheres of $\mathrm{Pt}\left(\eta^{2}-\mathrm{P}_{2} \mathrm{~L}\right)(\mathrm{XL})_{2}(\mathrm{X}=\mathrm{Ge}, \mathrm{Te}), \mathrm{Pt}\left(\eta^{2}-\mathrm{P}_{2} \mathrm{~L}\right)\left(\eta^{2}-\mathrm{X}_{2} \mathrm{~L}\right)(\mathrm{X}=\mathrm{As}, \mathrm{Ge}$, $\mathrm{Te})$ and $\mathrm{Pt}\left(\eta^{2}-\mathrm{P}, \mathrm{TeL}\right)$. In cis-Pt $\left(\eta^{2}-\mathrm{P}_{2} \mathrm{~L}\right)(\mathrm{GeL})_{2}$ complexes the

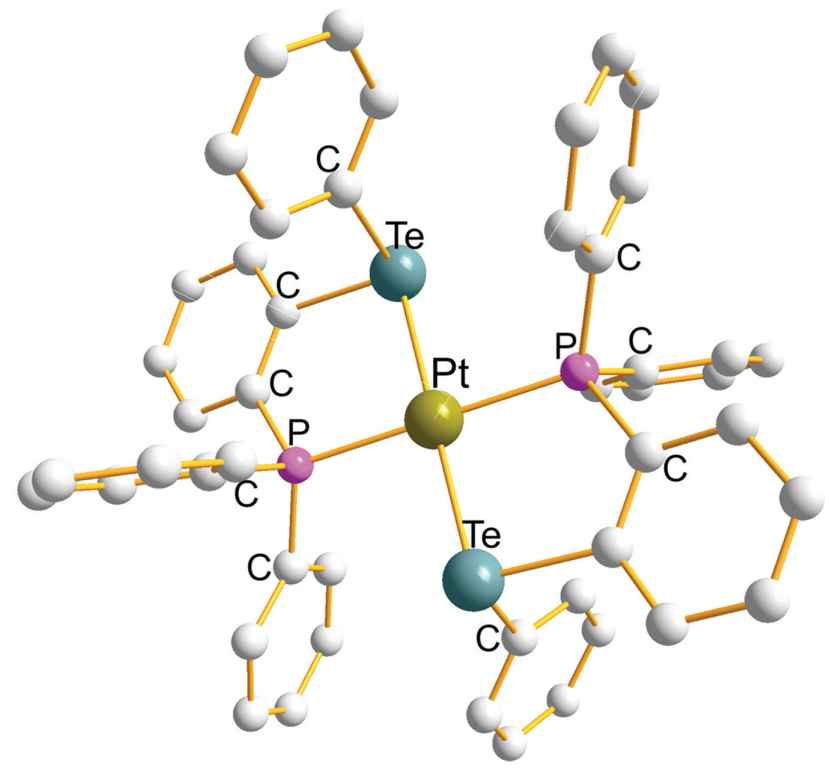

Figure 5: Structure of $\left[\mathrm{Pt}\left\{\mathrm{\eta}^{2}-\mathrm{Ph} \mathrm{P}_{2} \mathrm{P}\left(\mathrm{C}_{6} \mathrm{H}_{4}\right) \mathrm{TePh}\right\}_{2}\right]^{2+}$ (Gysling and Luss, 1984). mean values of Pt-P (trans to $\mathrm{Ge}$ ) and $\mathrm{Pt}-\mathrm{Ge}$ (trans to $\mathrm{P}$ ) bond distances are 2.286 and $2.471 \AA$, respectively. Such values in cis- $\mathrm{Pt}\left(\eta^{2}-\mathrm{P} L(\mathrm{TeL}){ }_{2}\right.$ are $2.261 \AA(\mathrm{Pt}-\mathrm{P})$ and $2.585 \AA$ (Pt-Te), respectively. In cis- $\mathrm{Pt}\left(\eta^{2}-\mathrm{P}_{2} \mathrm{~L}\left(\eta^{2}-\mathrm{X}_{2} \mathrm{~L}\right)\right.$ complexes the mean values are: 2.276 and $2.442 \AA(\mathrm{X}=\mathrm{As}) ; 2.283$ and $2.456 \AA(\mathrm{X}=\mathrm{Ge}) ; 2.254$ and $2.627 \AA(\mathrm{X}=\mathrm{Te})$, respectively. In trans-Pt $\left(\eta^{2}-\mathrm{P}, \mathrm{TeL}\right)_{2}$ complex the values are: $2.306 \AA$ ( $\mathrm{P}$ trans to P) and $2.575 \AA$ (Te trans to $\mathrm{Te}$ ).

The chelating donor ligands create varieties of metallocyclic rings which open in the sequence (mean values): $83.1^{\circ}(\mathrm{GeGeGe})<83.8^{\circ}\left(\mathrm{AsC}_{2} \mathrm{As}\right)<86.2^{\circ}\left(\mathrm{PC}_{2} \mathrm{P}\right)$ $<88.5^{\circ}\left(\mathrm{PC}_{2} \mathrm{Te}\right)<89.7^{\circ}\left(\mathrm{PC}_{3} \mathrm{P}\right) \sim 89.7^{\circ}\left(\mathrm{GeGe}_{2} \mathrm{Ge}\right)$. The sum of four (Pt-P(x2)) + (Pt-X(x2)) bond distances $\mathrm{Pt}\left(\eta^{2}-\mathrm{P}_{2} \mathrm{~L}\right)(\mathrm{XL})_{2}$ vs $P t\left(\eta^{2}-P_{2} L\right)\left(\eta^{2}-X_{2} L\right)$ are: 9.406 vs $9.481 \AA(X=G e)$; 9.692 vs $9.754 \AA$ ( $\mathrm{X}=\mathrm{Te})$. For $\mathrm{Pt}\left(\eta^{2}-\mathrm{P}_{2} \mathrm{~L}\right)\left(\eta^{2}-\mathrm{As}_{2} \mathrm{~L}\right)$ the value is $9.396 \AA$, and for $\mathrm{Pt}\left(\eta^{2}-\mathrm{P}, \mathrm{TeL}\right)_{2}$ is $9.762 \AA$. These values indicate that the inner coordination sphere in $\mathrm{Pt}\left(\eta^{2}-\mathrm{P}_{2} \mathrm{~L}\right)(\mathrm{XL})_{2}$ is somewhat more crowded than in its $\operatorname{Pt}\left(\eta^{2}-P_{2} L\right)\left(\eta^{2}-X_{2} L\right)$ partner.

This review together with its precursors (Holloway and Melnik, 2002, 2003, 2004; Melník and Mikuš 2019a, 2019b, 2020; Melník et al., 2019) have summarized and analyzed structural parameters of almost four hundred monomeric platinum(II) coordination complexes with an inner coordination spheres about the Pt(II) atoms of $\operatorname{Pt}\left(\eta^{2}-P_{2} L\right)(X L)_{2}(X=O L, N L, C N, B L, C l, S L, B r, S e L, S i L$, AsL, GeL, I, or TeL); $\mathrm{Pt}\left(\eta^{2}-\mathrm{P}_{2} \mathrm{~L}\right)\left(\eta^{2}-\mathrm{X}_{2} \mathrm{~L}\right)\left(\mathrm{X}=\mathrm{O}_{2} \mathrm{~L}, \mathrm{~N}_{2} \mathrm{~L}, \mathrm{~S}_{2} \mathrm{~L}\right.$, $\mathrm{Se}_{2} \mathrm{~L}, \mathrm{Si}_{2} \mathrm{~L}, \mathrm{As}_{2} \mathrm{~L}, \mathrm{Ge}_{2} \mathrm{~L}$ or $\left.\mathrm{Te}_{2} \mathrm{~L}\right)$; and $\mathrm{Pt}\left(\eta^{2}-\mathrm{P}, \mathrm{XL}\right)_{2}(\mathrm{X}=\mathrm{Si}$ or Te). In the $\mathrm{Pt}\left(\eta^{2}-\mathrm{P}_{2} \mathrm{~L}\right)(\mathrm{XL})_{2}$ derivatives the total mean Pt-P (trans to $\mathrm{X}$ ) bond distance elongate in the sequence: $2.216 \AA(\mathrm{X}=\mathrm{O})<2.233 \AA(\mathrm{Br})<2.240 \AA(\mathrm{I})<2.247 \AA(\mathrm{S})$ $<2.249 \AA(\mathrm{Se})<2.260 \AA(\mathrm{N})<2.261 \AA(\mathrm{Te})<2.286 \AA(\mathrm{Ge})$ $<2.290 \AA(\mathrm{Cl})<2.319 \AA(\mathrm{Si})<2.332 \AA(\mathrm{B})<2.335 \AA$ (C), and the total mean Pt-X (trans to $\mathrm{P}$ ) bond distance elongate in the sequence: $2.00 \AA(\mathrm{X}=\mathrm{C})<2.045 \AA(\mathrm{B})<2.090 \AA$ ( $)$ $<2.10 \AA(\mathrm{N})<2.350 \AA(\mathrm{S})<2.356 \AA(\mathrm{Cl})<2.365 \AA(\mathrm{Si})<2.455 \AA$ $(\mathrm{Se})<2.471 \AA(\mathrm{Ge})<2.490 \AA(\mathrm{Br})<2.585 \AA(\mathrm{Te})<2.666 \AA$ (I). As can be seen from the respective bond distances, the "soft" donor ligands show a larger trans-influence than the "borderline" or "hard" ones. The sum of all four $(\mathrm{Pt}-\mathrm{P}(\mathrm{x} 2)+\mathrm{Pt}-\mathrm{X}(\mathrm{x} 2)$ bond distances in these complexes with cis-configuration increases quite well with the covalent radius of the respective $\mathrm{X}$ donor atoms in the sequence: $8.61 \AA\left(\mathrm{PtP}_{2} \mathrm{O}_{2}\right)<8.67 \AA\left(\mathrm{PtP}_{2} \mathrm{C}_{2}\right)<8.72 \AA\left(\mathrm{PtP}_{2} \mathrm{~N}_{2}\right)$ $<8.75 \AA\left(\mathrm{PtP}_{2} \mathrm{~B}_{2}\right)<9.19 \AA\left(\mathrm{PtP}_{2} \mathrm{~S}_{2}\right)<9.29 \AA\left(\mathrm{PtP}_{2} \mathrm{Cl}_{2}\right)<9.37 \AA$ $\left(\mathrm{PtP}_{2} \mathrm{Si}_{2}\right)<9.41 \AA\left(\mathrm{PtP}_{2} \mathrm{Se}_{2}\right)\left(\mathrm{PtP}_{2} \mathrm{Ge}_{2}\right)<9.45 \AA\left(\mathrm{PtP}_{2} \mathrm{Br}_{2}\right)$ $<9.69 \AA\left(\mathrm{PtP}_{2} \mathrm{Te}_{2}\right)<9.81 \AA\left(\mathrm{PtP}_{2} \mathrm{I}_{2}\right)$.

In the $P t\left(\eta^{2}-P_{2} L\right)\left(\eta^{2}-X_{2} L\right)\left(X=O_{2} L, N_{2} L, S_{2} L, S_{2} L, S_{2} L\right.$, $\mathrm{As}_{2} \mathrm{~L}, \mathrm{Ge}_{2} \mathrm{~L}$, or $\mathrm{Te}_{2} \mathrm{~L}$ ) derivatives the total mean Pt-P (trans to $\mathrm{X})$ bond distance elongate in the sequence: $2.215 \AA$ $(\mathrm{X}=\mathrm{O})<2.242 \AA(\mathrm{N})<2.254 \AA(\mathrm{Te})<2.257 \AA(\mathrm{S})<2.262 \AA(\mathrm{Se})$ 
$<2.276 \AA(\mathrm{As})<2.283 \AA(\mathrm{Ge})<2.316 \AA$ (Si). The total mean Pt-X (trans to P) elongate in the sequence: $2.06 \AA$ ( $\mathrm{X}=0$ ) $<2.12 \AA(\mathrm{N})<2.328 \AA(\mathrm{S})<2.360 \AA(\mathrm{Si})<2.422 \AA(\mathrm{As})<2.455 \AA$ $(\mathrm{Se})<2.458 \AA(\mathrm{Ge})<2.627 \AA(\mathrm{Te})$. The sum of all four (Pt$\mathrm{P}(\mathrm{x} 2)+\mathrm{Pt}-\mathrm{X}(\mathrm{x} 2))$ bond distances in these complexes with cis-configuration growing in the sequence: $8.55 \AA$ $\left(\mathrm{PtP}_{2} \mathrm{O}_{2}\right)<8.72 \AA\left(\mathrm{PtP}_{2} \mathrm{~N}_{2}\right)<9.17 \AA\left(\mathrm{PtP}_{2} \mathrm{~S}_{2}\right)<9.35 \AA\left(\mathrm{PtP}_{2} \mathrm{Si}_{2}\right)$ $<9.40 \AA\left(\mathrm{PtP}_{2} \mathrm{As}_{2}\right)<9.43 \AA\left(\mathrm{PtP}_{2} \mathrm{Se}_{2}\right)<9.48 \AA\left(\mathrm{PtP}_{2} \mathrm{Ge}_{2}\right)<9.75 \AA$ $\left(\mathrm{PtP}_{2} \mathrm{Te}_{2}\right)$. As can be seen inner coordination sphere in $\mathrm{Pt}\left(\eta^{2}-\mathrm{P}_{2} \mathrm{~L}\right)\left(\eta^{2}-\mathrm{X}_{2} \mathrm{~L}\right)$ complexes is more crowded when $\mathrm{X}=\mathrm{O}$, $\mathrm{S}$ or $\mathrm{Si}$, and less crowded when $\mathrm{X}=\mathrm{Se}$, Ge or Te; than in the $\mathrm{Pt}\left(\eta^{2}-\mathrm{P}_{2} \mathrm{~L}\right)(\mathrm{XL})_{2}$ complexes. Noticeable, in the both types of complexes the volume of the inner coordination sphere is equal $(8.72 \AA)$ when $\mathrm{X}=\mathrm{N}$.

There are at least two contributing factors to the size of the L-Pt-L chelate bond angles both ligands based. One is the steric constraints imposed by the ligand, and the other is the need to accommodate the imposed ring size. The effects of both steric and electronic factors can be seen from the values of the L-Pt-L chelate angles. These angles open in the sequences (mean values):

four-membered: $65.0^{\circ}(\mathrm{SiOSi})<66.0^{\circ}(\mathrm{OCO})<70.9^{\circ}(\mathrm{PNP})$ $<73.5^{\circ}(\mathrm{PCP})<74.5^{\circ}(\mathrm{SCS})<77.8^{\circ}(\mathrm{SeCSe})$ $<83.1^{\circ}(\mathrm{GeGeGe})<85.3^{\circ}$ (SePSe);

five-membered: $78.9^{\circ}\left(\mathrm{NC}_{2} \mathrm{~N}\right.$, unsaturated $)<81.3^{\circ}\left(\mathrm{OC}_{2} \mathrm{O}\right)$ $<81.8^{\circ}\left(\mathrm{NC}_{2} \mathrm{~N}\right.$, saturated $)<83.1^{\circ}\left(\mathrm{SiC}_{2} \mathrm{Si}\right)$ $<83.8^{\circ}\left(\mathrm{AsC}_{2} \mathrm{As}\right)<84.0^{\circ}(\mathrm{PCOP})<86.1^{\circ}$ $\left(\mathrm{PC}_{2} \mathrm{P}\right)<86.9^{\circ}\left(\mathrm{PC}_{2} \mathrm{Si}\right)<87.5^{\circ}\left(\mathrm{SeSe}_{2} \mathrm{Se}\right)$ $<88.5^{\circ}\left(\mathrm{PC}_{2} \mathrm{Te}\right)<88.8^{\circ}\left(\mathrm{SiSi}_{2} \mathrm{Si}\right)<89.0^{\circ}$ $\left(\mathrm{SC}_{2} \mathrm{~S}\right)<89.7^{\circ}\left(\mathrm{GeGe}_{2} \mathrm{Ge}\right)$;

six-membered : $85.8^{\circ}(\mathrm{SCSCS})<87.0^{\circ}(\mathrm{SPNPS})<89.7^{\circ}$ $\left(\mathrm{PC}_{3} \mathrm{P}\right)<90.5^{\circ}(\mathrm{OPOPO})<91.2^{\circ}(\mathrm{OBOBO})$ $<92.1^{\circ}\left(\mathrm{SeC}_{3} \mathrm{Se}\right)<93.5^{\circ}\left(\mathrm{SC}_{3} \mathrm{~S}\right)<94.0^{\circ}$ $(\mathrm{PCNCP})<95.2^{\circ}(\mathrm{PCSiCP})<95.7^{\circ}(\mathrm{PCCNP})$ $<95.8^{\circ}(\mathrm{PCSCP} ; \mathrm{POCNP})<96.5^{\circ}$ (PCCOP) $<97.0^{\circ}$ (SPCPS);

seven-membered: $92.3^{\circ}\left(\mathrm{SC}_{4} \mathrm{~S}\right)<95.8^{\circ}\left(\mathrm{OC}_{4} \mathrm{O}\right)<98.2^{\circ}$ $\left(\mathrm{PC}_{4} \mathrm{P}\right)$.

It is hoped that this review well serve to draw together common structural threads and stimulate activity in areas of particular interest.

Acknowledgements: This work was supported by the projects VEGA 1/0463/18, and APVV-15-0585.

\section{References}

Arii H., Watanabe N., Mochida K., Kawashima T., Steric Effect of a Phosphane Ligand on the Equilibrium of $\mathrm{Ge}-\mathrm{Ge}$ Bond Formation at a Platinum Center. Eur. J. Inorg. Chem., 2012, 4791-4794, DOI:10.1002/ejic.201200782.

Braddock-Wilking J., Bandrowsky T., Praingam J., Rath N.P., Silaand Germaplatinacycles Produced from a Stepwise E-E Bond Forming Reaction. Organometallics, 2009, 28, 4098-4105, DOI:10.1021/om900201y.

Chauhan R.S., Kedanath G., Wadawale A., Maity D.K., Golen J.A., Rheingold A.C., et al., Cis configured bis phosphine platinum(II) chalcogenolate complexes: Structures, NMR and computational studies. J. Organomet. Chem., 2013, 737, 40-46, DOI:10.1016/j. jorganchem.2013.03.030.

Gysling H.J., Luss H.S., Synthesis and properties of the hybrid tellurium-phosphorus ligand phenyl o-(diphenylphosphino) phenyl telluride. X-ray structure of [Pt[PhTe(o-(PPh2C6H4)]2] [Pt(SCN)4].2DMF. Organometallics, 1984, 3, 596-598, DOI:10.1021/om00082a016.

Holloway C.E., Melnik M., Structural Aspect of Platinum Coordination Compounds: Part II. Monomeric Pt(II) Compounds with PtA3B and PtA2B2 Composition. Rev. Inorg. Chem., 2003, 23, 125-162, DOI:10.1515/REVIC.2003.23.2-3.125.

Holloway C.E., Melnik M., Structural aspects of platinum coordination compounds: PART I. Monomeric PT0, PT1 and PTIIA4 derivatives. Rev. Inorg. Chem., 2002, 22, 163-284, DOI:10.1515/ REVIC.2002.22.3-4.163.

Holloway C.E., Melnik M., Structural aspects of platinum coordination compounds: PART III. Monomeric square-planar (PtA2XY and PtABXY) and trigonal bipyramidal PtIl Coordination Compounds. Rev. Inorg. Chem., 2004, 24, 135-299, DOI:10.1515/ REVIC.2004.24.3.135.

Karjalainen M.M., Wiegand T., Niikko Rautainen J., Wagner A., Goris H., Weigand W., et al., Competitive Te-Te and C-Te bond cleavage in the oxidative addition of diaryl and dialkyl ditellurides to $\mathrm{Pt}(0)$ centers. J. Organomet. Chem., 2017, 836-837, 17-25, DOI:10.1016/j.jorganchem.2017.03.004.

Melník M., Holloway C.E., Stereochemistry of platinum coordination compounds. Coord. Chem. Rev., 2006, 250, 2261-2270, DOI:10.1016/j.ccr.2006.02.020.

Melník M., Mikuš P., Malík I., Organodiphosphines in cis-PtP2Se2 derivatives - Structural aspects. Inorg. Chim. Acta, 2019, 495, 118985.

Melník M., Mikuš P., Organodiphosphines in cis-Pt(g2-P2L) (g2-S2L) derivatives - structural aspects. Phosphorous Sulfur, 2019b, 194, 1015-1019, DOI:10.1080/10426507.2019. 1618302.

Melník M., Mikuš P., Organodiphosphines in cis-Pt(g2-P2L) (SR)2 derivatives - structural aspects. Phosphorous Sulfur, 2019a, 194, 857-860, DOI:10.1080/10426507.2019. 1597364.

Melník M., Mikuš P., Organomonophosphines in PtP2Cl2 derivatives: structural aspects. Rev. Inorg. Chem., 2015, 35, 179-190, DOI:10.1515/revic-2015-0004.

Melník M., Mikuš P., Organophosphines in PtP2Si2 derivatives structural aspects, Phosphorous Sulfur, 2020, 195, 367-370, DOI:10.1080/10426507.2019.1708360.

Mochida K., Wada T., Suzuki K., Hatanaka W., Nishiyama Y., Nanjo M., et al., Platinum-Catalyzed Bis-Germylation of Alkynes with Organodigermanes and Cyclic Oligogermanes. B. Chem. Soc. Jpn., 2001, 74, 123-137, DOI:10.1246/bcsj.74.123.

Risto M., Jahr E.M., Hannu-Kuure M.S., Oilunkaniemi R., Laitinen R.S., Structural and spectroscopic trends in mononuclear arylchal- 
cogenolato-palladium(II) and -platinum(II) complexes: Crystal structures of $[\mathrm{M}(\mathrm{TeAr}) 2(\mathrm{dppe})]\{\mathrm{M}=$ palladium, platinum; $\mathrm{Ar}=$ phenyl, 2-thienyl; dppe = 1,2-bis(diphenylphosphino) ethane\}. J. Organomet. Chem., 2007, 692, 2193-2204, DOI:10.1016/j.jorganchem.2007.01.039.

Rosenberg B., van Camp L., Trasko Y.T., Mansour V.H., Platinum Compounds: a New Class of Potent Antitumour Agents. Nature, 1969, 222, 385-386.

Tanabe M., Hanzawa M., Ishikawa N., Osakada K., Formation and Ring Expansion of Germaplatinacycles via Dehydrogenative $\mathrm{Ge}-\mathrm{Ge}$ and Ge-Pt Bond-Forming Reactions. Organometallics, 2009, 28, 6014-6019, DOI:10.1021/om900505k.
Tanabe M., Reguchi T., Osakada K., Chemical Properties of Tetragermaplatinacyclopentane. Insertion of an Alkyne into a Pt-Ge Bond and Silylation Caused by H2SiPh2. Organometallics, 2011, 30, 3386-3391, DOI:10.1021/om200275w.

Wagner A., Vigo L., Oilunkaniemi R., Laitinen R.S., Wiegand W., Oxidative addition of cyclic 1-oxa-5,6-ditelluraspirooctane to platinum(0) complexes. Dalton T., 2008, 3535-3537, DOI:10.1039/B802.

Weir M.L., Cade I.A., Kilah L., Zhou X., Wild S.B., Asymmetric Synthesis of Bis(tertiary arsines): Highly Stereoselective Alkylations of Diastereomers of a Chiral Phosphine-Stabilized Bis(arsenium triflate). Inorg. Chem., 2009, 48, 7482-7490, DOI:10.1021/ic900797y. 